Siegel, K. M. (2016) Fulfilling promises of more substantive democracy? Post-neoliberalism and natural resource governance in South America. Development and Change, 47(3), pp. 495-516. (doi:10.1111/dech.12234)

There may be differences between this version and the published version. You are advised to consult the publisher's version if you wish to cite from it.

This is the peer-reviewed version of the following article: Siegel, K. M. (2016) Fulfilling promises of more substantive democracy? Postneoliberalism and natural resource governance in South America. Development and Change, 47(3), pp. 495-516, which has been published in final form at $10.1111 /$ dech.12234. This article may be used for non-commercial purposes in accordance with Wiley Terms and Conditions for Self-Archiving.

http://eprints.gla.ac.uk/129766/

Deposited on: 10 October 2016

Enlighten - Research publications by members of the University of Glasgow http://eprints.gla.ac.uk 


\author{
Karen M. Siegel ${ }^{1}$ \\ Edinburgh Napier University \\ K.Siegel@napier.ac.uk
}

This is the peer reviewed version of the following article: Siegel, K.M. (2016) "Fulfilling promises of more substantive democracy? Post-neoliberalism and natural resource governance in South America", Development and Change, May 2016, volume 47, issue 3, pp. 495-516 which has been published in final form at http://onlinelibrary.wiley.com/doi/10.1111/dech.12234/abstract . This article may be used for non-commercial purposes in accordance with Wiley Terms and Conditions for Self-Archiving.

\title{
Fulfilling promises of more substantive democracy? Post-neoliberalism and natural resource governance in South America
}

\begin{abstract}
Benefitting from the commodity boom progressive governments across South America have sought to move away from the neoliberal policies adopted previously by strengthening the role of the state and using revenues from commodity exports to address social concerns. This approach, often called neo-extractivism, has become the main development strategy over the past 15 years. Yet, the increasingly intensive and extensive natural resource exploitation underlying this development strategy has also led to multiple protests and contestations across South America. This paper thus examines the relationship between neo-extractivism as a development strategy and the quality of democracy under progressive governments in South America. On the one hand, neo-extractivism has allowed states to become more inclusive by paying attention to social concerns which in turn has been an important element in the legitimacy of progressive governments. On the other hand, the reliance on neoextractivism as the main development strategy poses important constraints on the ability of post-neoliberal states to build more substantive democracies which could take into account a variety of positions, give citizens a say in decisions directly affecting their livelihoods and promote public debates on key questions confronting society.
\end{abstract}

\footnotetext{
${ }^{1}$ I would like to thank the three anonymous reviewers for their comments. I would also like to thank Mo Hume for her feedback on an earlier draft and Kelly Kollman for her support while working on the paper. Moreover, I am grateful to the Adam Smith Research Foundation at the University of Glasgow and the Society for Latin American Studies for funding the research that underpinned this paper.
} 
Karen M. Siegel (2016) "Neo-extractivism and democracy in South America" Development and Change, 47(3): 495-516

\section{INTRODUCTION}

Over the past 15 years a wave of Left or Left-of-centre governments have come to power in a majority of South American countries, starting with the election of the late Hugo Chávez in Venezuela in 1998. While these include very diverse governments, a crucial shared element is the commitment to reducing poverty and inequality as well as deepening democracy (Cannon and Kirby, 2012; Grugel and Riggirozzi, 2012; Panizza, 2009: 168-196). In an effort to move away from the neoliberal policy agenda that characterised the previous decades, progressive governments have reinforced the role of the state in order to target social concerns. Taking advantage of the commodity boom they have pursued a new strategy for economic and social development by using revenues from natural resource exports for much needed social programmes. Gudynas (2009) describes this as the neo-extractivism of progressive governments which combines old practices of natural resource exploitation with new social policies and a stronger role of the state. In this model income generated from export-led growth based on primary products has become the basis for economic and social development. This has led political leaders and some analysts to proclaim a new 'post-neoliberal' era (Grugel and Riggirozzi, 2012; Haarstad, 2012a; Riggirozzi and Tussie, 2012). However, post-neoliberalism does not represent a complete rupture with the past, but is better understood as 'an evolution, shaped by legacies of past development trajectories, pragmatism, ad hoc policy making and responses to global and regional politics.' (Riggirozzi and Tussie, 2012: 184).

In this context of continuity and change, the impacts of neo-extractivism as a development strategy have been complex and contradictory, particularly in relation to the quality of democracy. On the one hand, progressive governments have been successful in achieving some of their social objectives, notably decreasing poverty and inequality rates (Burchardt and Dietz, 2014: 473-474; Grugel and Riggirozzi, 2012: 10). This has made South American post-neoliberal states more inclusive and has increased the legitimacy of progressive governments and of the development strategy adopted (Gudynas, 2009). On the other hand, governments across South America have repeatedly faced protests in relation to projects associated with the 
Karen M. Siegel (2016) "Neo-extractivism and democracy in South America" Development and Change, 47(3): 495-516

exploitation of natural resources. Well-known cases include the protests against the Belo Monte dam and other hydropower developments in Brazil (Peters, 2011), the demonstrations against the construction of a highway in order to facilitate the transport of commodities through a protected area and indigenous territory, known as the TIPNIS, in Bolivia (Humphreys Bebbington and Bebbington, 2012: 25-28), the road blocks maintained for several years by a protest movement in Argentina against the construction of a large-scale pulp mill on the Uruguay River (Bueno, 2010: 171187; Waisbord and Peruzzotti, 2009), the civil society initiatives aimed at preventing the drilling for oil in the Yasuní national park in Ecuador (Certomà and Greyl, 2012) and wide-spread opposition to the Initiative for the Integration of Regional Infrastructure in South America (IIRSA) which includes a number of projects designed to facilitate the transport and export of commodities (Hochstetler, 2011: 144).

Clearly, the South American trend of relying on intensive resource exploitation as a development strategy is not uncontested despite its achievements in terms of economic growth and some social policies. In the first instance the various protests over resource exploitation of course reflect the concerns of communities directly affected and those wishing to promote socio-environmental concerns. However, taken together, the multiple contestations across South America also uncover shortcomings in the way liberal democracy functions and the difficulties of post-neoliberal states to take the various concerns expressed by civil society over resource governance into account. It is thus striking that citizens and civil society organisations do not necessarily advocate a complete stop to all resource exploitation, but rather demand a say in the location and extent of particular projects, as well as mitigation of negative impacts and a fair distribution of the burdens and benefits of intensive resource exploitation. While democracy has become embedded in South America and all countries hold regular elections and have formal democratic institutions, the multiple contestations over resource governance demonstrate citizen demands which go beyond casting a vote for designated representatives in elections every few years. Instead, citizens demand to have say in decisions directly impacting on their livelihoods and contribute to major debates in society. Such demands go beyond the existence of formal democratic institutions and are better understood through the 
notion of substantive democracy which highlights the need for meaningful participation in key decisions (Grugel, 2001: 5-6; Kaldor and Vejvoda, 1997).

The aim of this paper is thus to examine the relationship between neo-extractivism as a development strategy and the quality of democracy. I focus in particular on the progressive governments of South America due to their self-stated commitment to deepening democracy. While several studies have examined resource conflicts in the Andean-Amazonian countries (Bebbington, 2012a; Haarstad, 2012b; Veltmeyer and Petras, 2014), this paper looks at trends in South America as a whole drawing on evidence from the extraction of sub-soil resources in the Andean-Amazonian countries; the expansion of large-scale and intensive agricultural production based on the heavy use of agro-chemicals and genetically-modified organisms (GMOs) in the Southern Cone; and regional cooperation on natural resource governance. Whereas the quality of democracy in individual countries varies depending on a number of factors which go beyond the scope of this paper, the analysis uncovers a common trend that relying on neo-extractivism as the main strategy for development limits the possibilities available to post-neoliberal states in terms of building more substantive democracies. As neo-extractivism depends on increasingly intensive and extensive resource exploitation, it is hard to reconcile with the various concerns expressed by civil society as these would require setting some limitations to resource exploitation. While few limitations have been set during the commodity boom, these become even less politically feasible when prices fall. This is by no means relevant only for South America. In the context of high global commodity prices extractivism also presents an attractive source of income in other parts of the world and the path taken by South American progressive governments has given some grounds for hope that it is possible to pursue both, economic and social development. Examining this model in more detail and its impact on the quality of democracy is therefore highly relevant also for other countries.

In the following section I examine in more detail how neo-extractivism has become the main strategy for development through a combination of factors; the substantial increases in natural resource exploitation often promoted by state institutions; the use of revenues from the sector for social programmes; and the absence of other 
development strategies, most notably changes in the taxation systems. The subsequent section then turns to the impact of neo-extractivism on the quality of democracy. In order to understand this, it is helpful to break down the concept of democracy into different components. This shows that on the one hand states have become more inclusive and there have been increases in the legitimacy of governments, to a large extent due to the successful social programmes, as well as important changes in formal rules and rights benefitting previously highly marginalised groups. On the other hand, important limitations in relation to the practices of decision-making over resource exploitation remain and these have caused multiple protests. While contestations come from a range of different perspectives, citizens and civil society organisations regularly demand a say in decisions with very direct impacts on their livelihoods and often put forward alternative conceptions of development and sustainability. Yet, governments do not encourage public debates on natural resource governance and the development model adopted, and instead use a variety of discourses which justify intensive resource exploitation and sideline critical voices. Moreover, while some state institutions have been established for socioenvironmental concerns and participation mechanisms, these frequently do not function effectively and where interests conflict, those institutions promoting intensive resource exploitation tend to maintain the upper hand. All of this demonstrates that due to their adherence to neo-extractivism as the main strategy for development, progressive governments struggle to build more substantive democracies which would allow citizens to participate consistently in decisions directly affecting them and contribute to key debates in society. This also means that a redistribution of power relating to the control over natural resources has remained very limited. While South American countries do exhibit some aspects of rentier states (Burchardt and Dietz, 2014: 477; Weyland, 2009), this complex and contradictory picture suggests that there is no linear or straightforward relationship between natural resource wealth and democracy.

\section{NEO-EXTRACTIVISM AS A DEVELOPMENT STRATEGY}

Neo-extractivism has become the main strategy of progressive governments for economic and social development. This is evident in three trends observable across 
South America; first the substantial increases in natural resource exports over the last decade often promoted by government policies and state institutions; second social programmes building on revenues from natural resources; and third the absence of other strategies to address social concerns and inequality. While there are of course important variations between countries and economic sectors, these three aspects reflect developments across South America and thus provide evidence of a regional trend where neo-extractivism has become the main strategy for development (Burchardt and Dietz, 2014).

The export of natural resources is of course not a new phenomenon for South America and dates back to colonial times when Latin America became inserted into the global economy primarily as a commodity exporter to Europe (Galeano, 1973). However, as a result of high global prices and increasing demand from China the last 15 years have seen a trend of 'reprimarisation' (Svampa, 2012: 17) where South American countries have increasingly focussed on the production of primary commodities with little added value destined for export. Increases in natural resource exploitation are evident on a number of levels, including the volumes extracted, the share of commodities relative to other exports and the extent of areas used for resource exploitation. Primary commodities have come to represent a central and increasingly important economic sector for the region whose proportion in the total exports had reached over 80 per cent in a majority of South American countries by 2012 (ECLAC, 2013: 111). Due to the growing importance of China as a trading partner, the production of primary products has also increased in Brazil, the largest country in South America with the most diversified economy and export sector (Hochstetler, 2013: 40).

In the Andean-Amazonian countries, subsoil resources such as petroleum, gas and metals account for the largest share of resource exploitation. In Ecuador for example two-thirds of the Amazon has been designated for oil exploration and in Bolivia over half of the national territory has been marked as open to hydrocarbon exploitation (Bebbington, 2012b: 13). Meanwhile the Southern Cone countries have seen significant increases in the production and export of agricultural commodities, most notably soybean, but also sugarcane in the case of Brazil. Over the last decade agricultural exports have become highly profitable because of high global demand for 
Karen M. Siegel (2016) "Neo-extractivism and democracy in South America" Development and Change, 47(3): 495-516

biofuels and animal feed from countries in the global North and China as well as the introduction of new technologies, notably GMOs. In this context soybean has become the most important agricultural export of the Southern Cone countries. Argentinean exports thus increased in 33.5 billion dollars between 2004 and 2010 of which soy products accounted for 36.7 percent. While at the start of the millennium the soybean sector only accounted for 14 per cent of exports, this had risen to over 26 per cent by the end of the decade (Rivera-Quiñones, 2014: 75). The production of biodiesel in Argentina increased by 1500 percent between 2006 and 2012, and 650 percent in Brazil. At the same time ethanol production in Brazil has also increased by 40 percent between 2003 and 2012 (Fulquet, 2015: 50-51). These developments have been actively promoted by progressive governments who have created a number of state institutions, policies and incentives strengthening the agribusiness sector (Fulquet, 2015; Rivera-Quiñones, 2014; Vergara-Camus, 2015).

Given the increases in natural resource exploitation at the national level, it is not surprising that regional cooperation, too, has become 'resource-driven' (Saguier, 2012: 126) and following Brazil's lead at the start of the millennium South American governments launched IIRSA. This large-scale South America-wide initiative aims at improving the transport, energy and communications infrastructure, not least in order to facilitate commodity exports. With a budget of over US \$ 95 billion and over 500 planned projects which are often in frontier areas, the initiative aims to overcome considerable geographical barriers like the Andes or the Amazon basin (Carciofi, 2012; Garzón and Schilling-Vacaflor, 2012; Saguier, 2012: 130).

The second common trend is that progressive governments have strengthened the role of the state in the governance of natural resources and have used revenues from the export of commodities for much needed social programmes in the areas of poverty reduction, education or health. In Argentina for example a 20 per cent tax on exports of agricultural commodities and hydrocarbons was crucial to fund social emergency programmes following the 2001 crisis (Grugel and Riggirozzi, 2007: 96). Since then the revenues generated by the rapidly expanding soybean export sector have played a crucial role in providing Argentinean progressive governments with the fiscal space needed for social programmes (Rivera-Quiñones, 2014). In Uruguay and Brazil too, 
governments used the commodity boom and the strengthened economy to expand social programmes (Gudynas, 2009: 208; Zibechi, 2010: 107-108). Under the Bolsa Familia programme the Lula government thus extended social spending to over eleven million families, providing financial support under the condition that children attend school (Branford, 2009: 161). In the Andean countries of Ecuador and Bolivia progressive governments have renegotiated contracts in relation to subsoil resources and have used the revenues for expanding welfare programmes (Grugel and Riggirozzi, 2012: 8-9; Wolff, 2013: 41). In the case of Bolivia state revenues from the hydrocarbon sector have thus increased four-fold in the time period of 2006-2011 compared to the previous five years (Pellegrini and Ribera Arismendi, 2012: 108). Overall, such programmes have been successful in curbing extreme poverty and reducing inequality to some extent (Burchardt and Dietz, 2014: 473-474), although given the low starting point in terms of social spending, it has also been relatively easy for progressive governments to 'score quick wins' (Grugel and Riggirozzi, 2012: 8).

A final common element is that progressive governments across South America have been much less successful in terms of employing other strategies to address social concerns and inequality. In particular, progressive governments have not introduced significant changes to the very regressive taxation systems in place across South America (Burchardt and Dietz, 2014: 475; Cortés, 2009: 63) Consequently, the InterAmerican Development Bank has characterised the existing taxation systems in Latin America as a 'missed opportunity' (IDB, 2013: iii) which could be used much more effectively to address the high levels of income inequality and contribute to development more broadly. All in all it is therefore clear that progressive governments across South America have come to rely on neo-extractivism as their main strategy for economic and social development (Burchardt and Dietz, 2014).

\section{NEO-EXTRACTIVISM AND DEMOCRACY: INCREASING LEGITIMACY AND PARTICIPATION?}

The adoption of neo-extractivism as a development strategy has had complex and contradictory impacts on the quality of democracy. This section focuses on the 
democratic legitimacy of progressive governments and outlines how neo-extractivism has allowed leftist governments to gain a relatively high level of legitimacy largely as a result of the social programmes implemented (Gudynas, 2009). In the AndeanAmazonian countries of Ecuador and Bolivia this has been underpinned by important constitutional changes strengthening the rights of indigenous people. Under progressive governments states have thus become more inclusive and responsive to the concerns of previously highly marginalised parts of the population partly as a result of the revenues generated from neo-extractivism. This has been a significant element in the popularity of leftist governments and their re-election in several countries.

Political legitimacy is particularly important given that the election of leftist governments across South America has followed on from widespread protests against the neoliberal agenda pursued by previous governments and a widespread perception of the lacking democratic legitimacy of these governments. The liberal democracies established in South America in the 1980s and 1990s focussed on the procedural elements of democracy, notably voting and elections, but did not give the state any responsibility in terms of guaranteeing economic or social rights. Moreover, there was an expectation that the political leaders elected would recognise that neoliberal reforms represented the only path for economic development, so that the outcome of elections should not affect the policy reforms put in place. The consolidation of democracy was thus closely linked to neoliberal economic reforms where the role of the state primarily consisted of guaranteeing private property rights while social concerns and redistribution were off the agenda. At the same time governments repeatedly dismissed the concerns of poorer parts of the population as well as some middle-class issues (Silva, 2009: 25-28), exacerbating feelings of injustice and lacking democratic legitimacy.

Ultimately this brought down neoliberal governments in a number of South American countries and paved the way for the election of progressive governments. Many of the South American Leftist presidents have their roots in social movements and have come to power with the support of social movements (Prevost et al., 2012: 12-14) and on explicitly anti-neoliberal platforms (Panizza, 2009: 182-183). Reacting against the 
neoliberal reform agenda and its elitist practices of decision making, a commitment to democratic innovation and new possibilities of engaging civil society in decision making is therefore an important element in the approach of progressive governments (Brabazon and Webber, 2014: 436; Cannon and Kirby, 2012; Riggirozzi, 2012).

Natural resources are a crucial element in this respect as many South American citizens regarded the privatisation of natural resources under neoliberal governments as unfair and believed that the mineral wealth of their countries should benefit the people rather than foreign investors (Hogenboom, 2012; Perreault, 2008). Responding to citizen demands that natural resources should be treated as 'national' resources (Perreault, 2008: 249) by turning them into a source of revenue for social programmes has thus been an important cornerstone supporting the political legitimacy of progressive governments. At the same time, neo-extractivism as a development strategy has allowed progressive governments to make the liberal democracies established previously more inclusive by taking into account the concerns of poor people frequently ignored by previous governments (Grugel and Riggirozzi, 2012).

Furthermore, some progressive governments, particularly in the Andean-Amazonian countries, have taken steps towards changing the institutions and functioning of liberal democracy by adding new forms of participation and governance (Wolff, 2013). Specifically, the new constitutions adopted by governments in Bolivia and Ecuador have stressed the importance of indigenous rights, social justice and participation. The 2009 constitution of the Plurinational State of Bolivia became a leading example worldwide in recognising the rights of indigenous peoples (SchillingVacaflor, 2013: 202) while the Ecuadorian constitution adopted in 2008 is groundbreaking in formally recognising the rights of nature and giving a central space to indigenous perspectives on the relationship between humans and nature (Arsel, 2012). These constitutional changes are significant in strengthening the rights of citizens who had been highly marginalised for centuries and this has also increased their possibilities to mobilise and hold the state to account (Haarstad, 2012c: 244). These constitutional innovations constitute a move away from elitist practices of decision-making and provide substance to the self-stated commitment of progressive governments to improve the quality of democracy. Yet, when looking at the practices 
Karen M. Siegel (2016) "Neo-extractivism and democracy in South America" Development and Change, 47(3): 495-516

of decision-making under progressive governments a number of contradictions emerge which are particularly salient in the area of natural resource governance.

\section{REQUIRING MORE SUBSTANTIVE DEMOCRACY: CONTESTATIONS OVER NATURAL RESOURCE GOVERNANCE}

Notwithstanding the increases in perceptions of legitimacy under progressive governments, natural resource governance remains highly contested and some analysts have noted an 'explosion of socio-environmental conflicts' (Svampa, 2012: 19). Evidently, the contestations over resource governance encompass a multitude of different local context conditions, constellations of actors and demands which cannot be examined in detail in one paper. The citizens and civil society organisations protesting against particular projects of resource exploitation come from different backgrounds including indigenous groups, communities directly affected by resource exploitation and environmental NGOs, and they express a wide range of concerns such as access to land and natural resources, impacts on human health and livelihoods, demands for compensation, and environmental conservation (Svampa, 2012: 19-21).

Nevertheless, there are again some common trends which are significant for examining the quality of democracy in South American post-neoliberal states. In many cases what citizens and civil society organisations demand is thus not necessarily a complete stop to natural resource exploitation in principle, but a say in decision-making, for example in relation to the location and extent of extractivist projects, the mitigation of negative impacts or the distribution of burdens and benefits arising from intensive resource exploitation. Moreover, some of the civil society organisations and networks contesting resource governance have developed new frames of reference and discourses representing alternative understandings of development or sustainability (Svampa, 2012: 26).

The origins of the multiple contestations over resource governance therefore lie largely in the widespread dissatisfaction in relation to decision-making practices in resource governance and uncover shortcomings in the way democracy functions. Consequently, focussing on regular elections and formal democratic institutions alone 
is not sufficient to understand the nature of the conflicts over resource governance. Instead, I build on the notion of substantive democracy which captures two elements in particular which are crucial to understand the nature of the contestations over resource governance; the ability of citizens to have a say in decisions directly affecting them and to contribute to major debates in society; and the ability of states to take a variety of positions into account and mediate in situations of conflict.

Substantive democracy has been defined as 'a way of regulating power relations in such a way as to maximize the opportunities for individuals to influence the conditions in which they live, to participate in and influence debates about the key decisions which affect society' (Kaldor and Vejvoda, 1997: 62). This captures several aspects which are highly relevant to understand the ongoing protests over resource governance across South America. First, it calls for as many opportunities as possible for participation in decision-making. Casting a vote in elections every few years should thus not be the only way citizens can participate. This is particularly important in relation to two types of decisions; first decisions directly affecting citizens' environments and livelihoods; and second decisions regarding central debates affecting society as a whole. Clearly, this is highly relevant in relation to natural resource exploitation which frequently has very direct impacts on local communities and which is at the heart of development strategies, one of the central issues for South American societies. This is also closely related to the idea of social citizenship and citizenship rights, including the right to have a say in decisions directly affecting citizens (Grugel, 1999: 159). Social citizenship has also been defined as having 'a voice in the allocation of public resources rather than in the designation of public authorities' (Arditi, 2008: 76). In a situation where natural resources form the basis of public resources, this can be extended to having a say in whether, to what extent and how natural resources are exploited. Giving citizens a greater say in order to build more substantive democracy would also imply a redistribution of power (Grugel, 2001: 5). In the context of natural resource governance, this relates to the control over resources. A second important element of substantive democracy relates to the role of the state and its ability to take a variety of positions into account; and to be flexible and able to mediate in situations of conflict (Grugel, 2001: 243-244). Again, this is 
Karen M. Siegel (2016) "Neo-extractivism and democracy in South America" Development and Change, 47(3): 495-516

highly relevant in relation to the variety of concerns expressed in relation to natural resource exploitation.

In the Andean-Amazonian countries increasingly intensive exploitation of sub-soil resources such as gas, petroleum and metals has repeatedly led to contestations by affected communities and civil society organisations which have been relatively well researched (Bebbington, 2012a; Haarstad, 2012b; Veltmeyer and Petras, 2014). In many cases the areas opened up for resource exploitation overlap with indigenous territories and/or protected areas. According to EJOLT ${ }^{2}$ out of 342 environmental justice conflicts currently registered for South America, 197 conflicts are located in the Andean-Amazonian countries of Bolivia, Colombia, Ecuador, Peru and Venezuela (EJOLT, 2015). However, in many cases protests are not against resource exploitation per se, but rather demonstrate various and complex claims over territory, sovereignty and compensation. Such claims are made in relation to both, the state and companies carrying out resource exploitation. Instead of wanting to halt extraction completely, protestors look for 'a form of extraction that respects them, their cultures, their livelihoods and their territorial claims' (Bebbington, 2012c: 224). Important concerns of those challenging extraction of subsoil resources are thus the distribution of costs and benefits of extraction and real possibilities for participation in decision making.

While fewer conflicts have been reported in relation to the Southern Cone region of Argentina, Paraguay, Uruguay and the south of Brazil, the spread of intensive agriculture and consolidation of agribusiness has not been uncontested. Across the Southern Cone communities living in areas of intensive agricultural production have been concerned about the impact of agro-chemicals on human health (Robinson, 2008: 89; Wandscheer, 2009). In Argentina for example specialists from various branches of medicine have concluded that exposure to pesticides used in the region increases health risks, in particular cancer, miscarriages, malformations and impaired fertility. Affected communities and citizen associations have used these arguments to protest against fumigation by air and to take farmers using agro-chemicals to court

\footnotetext{
${ }^{2}$ EJOLT is a global research project analysing ecological distribution conflicts. The project compiles an environmental justice atlas and database of environmental conflicts regularly updated by researchers and civil society all over the world.
} 
Karen M. Siegel (2016) "Neo-extractivism and democracy in South America" Development and Change, 47(3): 495-516

(Cáceres, 2014: 19; Giarracca and Teubal, 2014: 60-61). Moreover, environmental organisations in various Southern Cone countries have stated their opposition to the use of GMOs and have put biosafety on the top of their agendas (Newell, 2008: 351$352)$.

Intensive agricultural production as it is pursued in the Southern Cone and the increasing power of agribusiness have also been challenged on the grounds of wider social issues and in particular the distribution of wealth and assets. Conflicts over land between peasants and indigenous communities on the one hand and agribusiness on the other have thus intensified in many places in the region over the past decade and have become particularly salient in Paraguay (Cáceres, 2014; Giarracca and Teubal, 2014: 58; Segovia, 2009; Yanosky, 2013). In June 2012 it was also a conflict of this nature and the question of land rights more generally that led to the impeachment of the Paraguayan president at the time, Fernando Lugo, demonstrating the importance of the issue for Paraguayan politics (Lambert and Nickson, 2013). In addition to land rights, regional civil society networks have also drawn attention to the right to water and argued that this is equally threatened by the significant deterioration of the water quality as a result of land use changes (Celiberti and Taks, 2009; Iglesias and Taks, 2009). Moreover, the landless movement in Brazil has highlighted the importance of food sovereignty (Newell, 2008: 352), an issue that is equally threatened by the expansion of export-oriented agricultural production.

Civil society organisations have also been concerned about the increase in agricultural production over the last two decades because this has led to an expansion of the agricultural frontier, with soybean plantations either directly pushing into new areas, such as the Brazilian Cerrado, one of the biologically richest savannas in the world (Wolford, 2008), or displacing traditional activities, notably cattle-ranching, and pushing these into new areas. These processes are also associated with large-scale deforestation across the Southern Cone (Cáceres, 2014: 8; Fulquet, 2015: 49; Giarracca and Teubal, 2014: 58). To counteract this trend regional networks of environmental NGOs have for example created the Grasslands Alliance with the aim of promoting alternative and more environmentally sustainable ways of agricultural production (Grasslands Alliance, 2015; Siegel, 2014: 146-169). 
Finally, IIRSA, the largest regional project promoting resource exploitation in South America has also been heavily contested. Many IIRSA projects are large-scale and in remote areas and thus have significant consequences for the lives of people and the physical environment. Although some assessments of environmental and social impact have been carried out, these have come late and have been applied inconsistently, thus not meeting the ambitious targets that had been set (Hochstetler, 2011: 143-144, 2013: 43-44). Due to the social and environmental impacts and the lack of effective consultation mechanisms, IIRSA has faced large-scale regional opposition of civil society groups and affected communities (Garzón and SchillingVacaflor, 2012; Hochstetler, 2011: 144; Saguier, 2012: 134-135). Overall, the new forms of regional integration that have been developed over the last decade have therefore not been matched by corresponding regional institutional channels to address socio-environmental concerns.

In the first instance, these contestations of course demonstrate the significant grievances of communities directly affected by intensive resource exploitation and the concerns of groups wishing to promote socio-environmental objectives. However, taken together they also demonstrate shortcomings in the way liberal democracy functions in South American post-neoliberal states, exposing citizen demands which go beyond casting a vote for designated representatives every few years. Instead citizens demand a say in decisions directly affecting them and advocate that a wider range of concerns should be taken into account in natural resource governance. Moreover, some civil society organisations put forward alternative conceptions of development and sustainability. All of these elements demonstrate a need for more substantive democracy which takes into account a variety of concerns and gives citizens a say in decisions with immediate impacts on their livelihoods and in broader societal debates.

\section{UNCOVERING THE LIMITATIONS OF DEMOCRATIC INNOVATION UNDER NEO-EXTRACTIVISM: THE RESPONSES OF GOVERNMENTS}


While neo-extractivism has allowed progressive governments to respond to some of the criticisms of democracy under neoliberalism by redirecting some revenues to social programmes and making states more inclusive, the government responses to the multiple contestations over resource exploitation clearly demonstrate the limitations in terms of building more substantive democracies. The approach of progressive governments to natural resource governance demonstrate a common trend combining two elements; on the one hand, different types of discourses justifying intensive resource exploitation towards the outside often with the support of international and domestic business; and on the other hand an internal prioritisation of intensive resource exploitation over other concerns. This approach has hindered the development of more substantive democracy taking into account the various concerns expressed by civil society groups and giving citizens a say in decisions directly affecting them. It has also served to shut down rather than open up the space for public debates on resource governance and on the development model adopted. In this context alternative discourses and conceptions of development have remained marginal and have not been able to generate wider debates in society (Svampa, 2012: 26) while public opinion has been relatively favourable (Gudynas, 2014).

Nevertheless, the multiple contestations over resource governance clearly demonstrate that a range of citizen concerns exist which are difficult to address without imposing limitations to intensive resource exploitation. Significantly, such concerns are often expressed by minority groups with limited access to decision-making processes (Gudynas, 2014: 151). As a consequence it is difficult to say to what extent there is a social consensus on neo-extractivism as the main development strategy. Finally, the adherence to neo-extractivism has also meant that there has not been any significant redistribution of power in relation to the control over resources. This has made progressive governments vulnerable to charges of abandoning objectives they had held previously.

\section{Justifying intensive resource exploitation}

Progressive governments have used a variety of discourses to defend intensive resource exploitation referring to the need to address poverty and the abundance of resources available as well as particular sets of scientific knowledge and framings. 
Given the strengthening of indigenous rights that has taken place simultaneously, some of the most surprising and frequently cited verbal responses to protestors have come from progressive governments in the Andean-Amazonian countries. In Bolivia, President Evo Morales has thus stated 'what then is Bolivia going to live off if some NGOs say “Amazonia without oil"... They are saying, in other words, that the Bolivian people ought not have money, that there should be neither Impuesto Directo a Hidrocarburos [Direct Hydrocarbons Tax] nor royalties, and also that there should be no Juancito Pinto, Renta Dignidad nor Juana Azurduy programmes' (as quoted in Bebbington, 2012b: 10) ${ }^{3}$. In neighbouring Ecuador President Rafael Correa has stated that it would be stupid and irresponsible not to exploit the resources available and 'beg while sitting on a sack of gold' (Gudynas, 2010a: 65, author's translation). Furthermore, indigenous communities in Bolivia asking for respect for indigenous issues, territorial claims and consultation were accused of being part of the 'fascist right that seeks to hinder the development' of the country (Bebbington, 2012b: 11) while Correa has labelled protestors 'extortionists', 'terrorists' or 'infantile leftists and romantic ecologists' (Bebbington, 2012b: 11-12). Such declarations can be seen as an attempt on the part of governments to justify intensive resource exploitation and shut down public debates over resource governance, by presenting a discourse of no alternative where natural resource governance is seen as a choice between environmental protection and poverty reduction and where critical points of view are discredited. This approach does not engage with the different concerns put forward by civil society and it makes public debates all the more polarized while making it easier to dismiss citizen concerns and leaving no space to discuss the overarching strategy of development.

In the Southern Cone governments, transnational companies and large parts of the media have converged to defend the expansion of large-scale intensive agriculture with reference to a particular set of scientific frames and expert knowledge and more recently also climate change and the need to develop 'clean' sources of energy. In relation to the Brazilian Cerrado, the dominant discourse of journalists, policy makers and academics established that large-scale intensive agriculture is a 'logical' response

\footnotetext{
${ }^{3}$ Juancito Pinto, Renta Dignidad and Juana Azurduy are social assistance programmes. See also (Gudynas, 2010a: 67)
} 
to the characteristics of this area because the soil needs intensive treatment and the flat topography makes it ideal for the use of machinery (Wolford, 2008: 216). Moreover, Brazil's former president Lula of the Worker's Party has repeatedly praised the benefits of biofuel production stressing economic and social benefits in national and international forums (Vergara-Camus, 2015: 230-233). In Argentina too, agroindustrial experts who promote intensive agriculture and the use of GMOs with reference to scientific arguments have played a central part in the expansion of intensive agriculture and its justification (Córdoba, 2014: 6). Moreover, the agribusiness sector has been successful in building strong ties with policy makers and biotechnology corporations benefit from close links with the government and formal access to decision making. Together with their enormous material resources this means that transnational companies are in a strong position to shape government agendas. Biotechnology corporations have also used their influence and resources to access and sponsor mass media, resulting in a discourse in favour of GM technology which dominates the political and public sphere (Newell, 2009). Finally, increasing concerns about climate change and a search for 'clean' energy in countries of the global North has provided further justifications for developing biofuel production in the Southern Cone countries (Fulquet, 2015: 49).

At the regional level the prominent discourse has focussed on the abundance of resources available and the role of national governments in exploiting these. In June 2013 the regional organisation Unasur thus held a meeting with the objective of developing a joint strategy for the exploitation of natural resources in South America. The discourse put forward at this meeting stressed the existence of abundant resources which need to be exploited to guarantee the well-being of the people and which are so vast that they can satisfy the demands of the region and requirements of countries outside the region. Moreover, the meeting reaffirmed the position of the nation-states as the owners of natural resources (Secretaría General de la UNASUR, 2013). The position agreed by governments across the region thus defends an economic model based on the export of natural resources and stresses that the national level and therefore the governments themselves rather than affected communities, is the appropriate scale to take decisions in relation to natural resource governance. The Unasur meeting in 2013 partly echoed the conclusions of another regional meeting a 
few years earlier, the ALBA summit in 2010. Here, South American leaders from across the political spectrum had agreed that the right to prior consultation of communities affected by resource exploitation was a regrettable obstacle for policies decided at the national level (Haarstad and Campero, 2012: 100). At the same time, socio-environmental impacts or potential risks as well as the positions of civil society do not seem to receive a lot of attention. On the contrary, references to the vast extent of resources available are a way of implying that scarcity or degradation of resources is not a problem (Gudynas, 2011: 64-65).

\section{Internal prioritisation of intensive resource exploitation}

The external justification of intensive resource exploitation has gone hand in hand with an internal prioritisation of resource extraction over other concerns. This has also meant that a redistribution of power in relation to the control over natural resources has been very limited. Although environmental concerns have gained a more prominent place on political agendas of most South American states following the return to democracy in the 1980s, environmental agencies often suffer from a weak institutional position and very limited resources (Mumme and Korzetz, 1997). According to Gudynas (Gudynas, 2014: 143-144) the focus on extractivism has further isolated environmental agencies and in the Uruguayan case for example, led to its dismantling under progressive president Mujica. Meanwhile the regional Unasur organisation which was established in the last decade, has councils on a number of policy areas, including energy, health or social development, but there is no council dedicated to socio-environmental concerns.

Furthermore, the resignation of ministers or high-level officials promoting more stringent environmental protection and limiting the scale or intensity of resource exploitation has been a recurring pattern in South American progressive governments. This includes Marina Silva, a well-respected environmentalist who became Brazil's Environment Minister during the first Lula government in 2003. However, after frequently being overruled within the administration, disagreements over planned infrastructure developments in the Amazon played a key role in her resignation five years later (Branford, 2009: 166-168; Hochstetler and Keck, 2007: 178-180). In 
Karen M. Siegel (2016) "Neo-extractivism and democracy in South America" Development and Change, 47(3): 495-516

Ecuador Alberto Acosta who had close links with environmental and indigenous movements and questioned the country's reliance on resource extraction, was initially Minister of Mining and Energy in the Correa government, but left due to disagreements with Correa over resource extraction (Humphreys Bebbington and Bebbington, 2012: 28-29; Moore and Velásquez, 2012). Meanwhile, in Bolivia, the vice minister of the environment and a subdirector both stood down from their positions in the Morales government as they did not want to support the TIPNIS project (Humphreys Bebbington and Bebbington, 2012: 27). Finally, in Argentina the absence of a strategy to address climate change led Raúl Estrada Oyuela, a high-level diplomat in the Foreign Office working on the topic, to comment that Argentina did not have an environmental policy. He criticized the country's lack of data on environmental concerns and commented that it is not possible to regulate mining or industry. Shortly afterwards his position was abolished, but there was no response as to what the environmental policy consists of (Estrada Oyuela, 2009; Obarrio, 2007).

The prioritisation of intensive resource exploitation has also led to a series of contradictions and limited a redistribution of power with regards to the control of natural resources. In Bolivia the right of indigenous communities to free prior and informed consultation in relation to the exploitation of natural resources is enshrined in the new constitution that was adopted by popular referendum in 2009 and the Hydrocarbon Law of 2005. Yet, when it comes to decision-making in practice, the picture is far more problematic. Schilling-Vacaflor (2013) thus found that meaningful possibilities for participation in decision-making in the hydrocarbon sector have remained very limited in particular because consultation took place only very late in the planning process and withholding consent did not appear to be a viable option for affected communities. Consequently, communities could only negotiate over the details of implementation and compensation payments while larger debates over the development model adopted by the Bolivian state remained firmly off the agenda. Several studies have noted that the origins for the shortcomings in the consultation procedures lie in the development model adopted by the Bolivian government which prioritises resource extraction and related infrastructure projects over alternative visions of development because the state depends on income from the resource sector for its social programmes (Pellegrini and Ribera Arismendi, 2012: 115; Schilling- 
Karen M. Siegel (2016) "Neo-extractivism and democracy in South America" Development and Change, 47(3): 495-516

Vacaflor, 2013: 216). In Ecuador, indigenous, campesino and environmental activists and lawyers argued that a law approved in 2009 favouring large-scale mining contradicted indigenous principles enshrined in the new constitution adopted the year before (Moore and Velásquez, 2012: 127).

Contradictions are also evident in the Southern Cone, particularly in relation to the question of land reform. Brazil thus adopted GMO technology which transnational agricultural companies strongly pushed for, under Leftist President Lula despite the fact that he had previously criticized this type of agricultural production (Gudynas, 2010b: 38; Hochstetler and Keck, 2007: 180). Moreover, following his election victory Lula introduced some changes, but overall took a far more moderate approach on the question of land reform than he had advocated previously, thus disappointing the hopes of the landless movement who had supported him in the 2002 election (Branford, 2009; Newell, 2008). Several authors thus see a clear link between the expansion of agribusiness and the lack of land reform under both, Lula and his successor from the Worker's Party Dilma Rousseff who has been the Brazilian President since 2011 (Fulquet, 2015: 47-48; Vergara-Camus, 2015: 229). Similarly, in Bolivia land reform under the Morales government has been very limited while medium and large enterprises have continued to thrive (Brabazon and Webber, 2014). Overall, the prioritisation of increasingly intensive and extensive resource exploitation over other concerns on the part of progressive governments has severely limited the possibilities of post-neoliberal states in building more substantive democracies. The reliance on neo-extractivism makes it difficult to take multiple views on natural resource governance into account and does not encourage a redistribution of control over natural resources.

\section{CONCLUSION}

This paper has argued that the increasingly intensive and extensive resource exploitation that forms the basis of the development strategy adopted by progressive governments in South America over the past 15 years is hard to reconcile with the variety of concerns expressed by citizens in relation to natural resource governance. Accommodating the different positions expressed by citizens would require setting 
some limitations to the extent of resource exploitation; yet this is difficult as long as neo-extractivism is the main development strategy. While neo-extractivism has thus led to some increases in the legitimacy of progressive governments, the building of more substantive democracies giving citizens a say in decisions directly affecting them, encouraging public debates on key questions confronting society and taking into account a variety of concerns, remains elusive.

This also raises the question of why progressive governments continue to rely on neoextractivism as the main strategy for development. After all the contestations over resource governance have often alienated former allies and led to new divisions within the left. At the same time progressive governments also face significant challenges by the right which is evident for example in the recent protests against the Rousseff government in Brazil (Saad-Filho, 2015). On the one hand, the contestations over resource governance demonstrate that building democracy is a messy and incremental process. Democratisation is not a linear process as Cannon and Hume also demonstrate in their analysis of Central American progressive governments (Cannon and Hume, 2012). This makes contradictions more likely. On the other hand, analysing contestations over resource governance in South America also points to important constraints imposed by international and domestic business actors which deserve more attention in future studies. In Bolivia representatives of transnational and domestic corporations thus lobbied against the strengthening of indigenous rights (Schilling-Vacaflor, 2014: 9) while in Ecuador Canadian companies and politicians lobbied in favour of contentious mining projects (Moore and Velásquez, 2012). At the same time, bilateral investment treaties grant foreign investors significant protection while limiting the policy tools available to governments (Haarstad and Campero, 2012). In Argentina, the US embassy promoted the interests of TNCs and in particular Monsanto (Zenteno Hopp et al., 2015: 86).

Business interests thus represent a powerful lobby which is sometimes supported by Northern governments and which can present a strong opposition to changing practices in decision-making and giving citizens a greater say. Neo-extractivism has therefore also allowed progressive governments to maintain a fragile equilibrium keeping domestic and international business interests satisfied while implementing a 
Karen M. Siegel (2016) "Neo-extractivism and democracy in South America" Development and Change, 47(3): 495-516

minimum of social programmes. In this context, perhaps progressive governments have come to regard neo-extractivism as 'their only option' (Bebbington, 2012c: 222; Schilling-Vacaflor, 2013: 204). This would confirm that substantive democracy in marginalized regions of the global South is hard to achieve in the context of globalized capitalism (Grugel, 2001: 10; 241) as even governments committed to deepening democracy in a favourable economic context seem to find their margin to manoeuvre restricted. Yet, business interests include many different groups with very different objectives and relationships to the state and communities affected by resource exploitation. The impact on decision-making procedures and democratic quality is therefore likely to be uneven and needs to be examined further through more systematic research. 
Karen M. Siegel (2016) "Neo-extractivism and democracy in South America" Development and Change, 47(3): 495-516

\section{REFERENCES}

Arditi, B. (2008) 'Arguments about the Left Turns in Latin America - A Post-Liberal Politics?' Latin American Research Review 43 (3): 59-81.

Arsel, M. (2012) 'Between "Marx and Markets"? The State, the "Left Turn" and Nature in Ecuador' Tijdschrift Voor Economische En Sociale Geografie 103 (2): 150-63.

Bebbington, A. (ed.) (2012a) Social Conflict, Economic Development and Extractive Industry - Evidence from South America. Oxon: Routledge.

Bebbington, A. (2012b) 'Extractive Industries, Socio-Environmental Conflicts and Political Economic Transformations in Andean America' in Bebbington, A. (ed.) Social Conflict, Economic Development and Extractive Industry - Evidence from South America. Oxon: Routledge.

Bebbington, A. (2012c) 'Conclusions' in Bebbington, A. (ed.) Social Conflict, Economic Development and Extractive Industry - Evidence from South America. Oxon: Routledge.

Brabazon, H. and J.R. Webber (2014) 'Evo Morales and the MST in Bolivia: Continuities and Discontinuities in Agrarian Reform' Journal of Agrarian Change 14 (3): 435-65.

Branford, S. (2009) 'Brazil: Has the Dream Ended?' in Lievesley, G. and Ludlam, S. (eds) Reclaiming Latin America: Experiments in Radical Social Democracy, pp.153-69. London: Zed Books.

Bueno, M. del P. (2010) De Estocolmo a La Haya - La Desarticulación de Las Políticas Ambientales En La Argentina (From Stockholm to The Hague - The Fragmentation of Environmental Policies in Argentina). Rosario: UNR Editora Editorial de la Universidad Nacional de Rosario.

Burchardt, H.-J. and K. Dietz (2014) '(Neo-)extractivism - a New Challenge for Development Theory from Latin America' Third World Quarterly 35 (3): 46886.

Cáceres, D.M. (2014) 'Accumulation by Dispossession and Socio-Environmental Conflicts Caused by the Expansion of Agribusiness in Argentina' Journal of Agrarian Change early view: 1-32.

Cannon, B. and M. Hume (2012) 'Central America, Civil Society and the 'Pink Tide': Democratization or de-Democratization?' Democratization 19 (6): 1039-64.

Cannon, B. and P. Kirby (2012) 'Civil Society - State Relations in Left-Led Latin America: Deepening Democratization?' in Cannon, B. and Kirby, P. (eds) Civil 
Karen M. Siegel (2016) "Neo-extractivism and democracy in South America" Development and Change, 47(3): 495-516

Society and the State in Left-Led Latin America - Challenges and Limitations to Democratization, pp. 189-202. London: Zed Books.

Carciofi, R. (2012) 'Cooperation for the Provision of Regional Public Goods: The IIRSA Case' in Riggirozzi, P. and Tussie, D. (eds) The Rise of Post-Hegemonic Regionalism - The Case of Latin America, pp.65-79. Dordrecht: Springer.

Celiberti, L. and J. Taks (eds) (2009) El Acuífero Guaraní En Debate (Debating the Guaraní Aquifer). Montevideo: Cotidiano Mujer.

Certomà, C. and L. Greyl (2012) 'Nonextractive Policies as a Path to Environmental Justice? The Case of the Yasuní Park in Ecuador' in Haarstad, H. (ed.) New Political Spaces in Latin American Natural Resource Governance, pp. 199-216. New York: Palgrave Macmillan.

Córdoba, M.S. (2014) 'Ensamblando actores - Una mirada antropológica sobre el tejido de alianzas en el universo del agronegocio' (Putting Together Different Actors - An Anthropological View on the Web of Alliances in the World of Agribusiness) Working Paper Series No. 68. Berlin: desiguALdades.net. http://www.desigualdades.net/Working_Papers/index.html (accessed 15 September 2014).

Cortés, R. (2009) 'Social Policy in Latin America in the Post-Neoliberal Era' Governance after Neoliberalism in Latin America. New York: Palgrave Macmillan.

ECLAC (2013) Statistical Yearbook for Latin America and the Caribbean 2013. Santiago de Chile: United Nations.

EJOLT (2015) 'Environmental Justice Atlas'. http://ejatlas.org/ (accessed 12 June 2015)

Estrada Oyuela, R. (2009) 'Falta una política ambiental' (There is No Environmental Policy) La Nacion, 21 November 2009. http://www.lanacion.com.ar/1202311falta-una-politica-ambiental (accessed 15 September 2014).

Fulquet, G. (2015) ‘La Maldición de Los Recursos Naturales? Conocimiento Experto, Política Y Intereses Sectoriales En El Desarrollo de Biocombustibles En Sudamérica' (The Curse of Natural Resources? Expert Knowledge, Politics and Sectoral Interests in the Development of Biofuels in South America) Brazilian Journal of International Relations 4 (1): 39-70.

Galeano, E. (1973) Open Veins of Latin America. New York: Monthly Review Press.

Garzón, J. and A. Schilling-Vacaflor (2012) 'Infrastrukturprojekte zwischen geopolitischen Interessen und lokalen Konflikten' (Infrastructure Projects Between Geo-Political Interests and Local Conflicts) GIGA Focus Lateinamerika No. 10/2012. Hamburg: German Institute of Global and Area Studies. 
Karen M. Siegel (2016) "Neo-extractivism and democracy in South America" Development and Change, 47(3): 495-516

http://www.giga-hamburg.de/de/publikationen/giga-focus/lateinamerika (accessed 15 September 2014).

Giarracca, N. and M. Teubal (2014) 'Argentina: Extractivist Dynamics of Soy Production and Open-Pit Mining' in Veltmeyer, H. and Petras, J. (eds) The New Extractivism: A Post-Neoliberal Development Model or Imperialism of the Twenty-First Century?, pp. 47-79. London: Zed Books.

Grasslands Alliance (2015) http://www.alianzadelpastizal.org (accessed 18 December 2015)

Grugel, J. (1999) 'Contextualizing Democratization - The Changing Significance of Transnational Factors and Non-State Actors' in Grugel, J. (ed.) Democracy without Borders - Transnationalization and Conditionality in New Democracies, pp. 3-22. London: Routledge.

Grugel, J. (2001) Democratization: A Critical Introduction. Houndmills: Palgrave Macmillan.

Grugel, J. and P. Riggirozzi (2007) 'The Return of the State in Argentina' International Affairs 83 (1): 87-107.

Grugel, J. and P. Riggirozzi (2012) 'Post-Neoliberalism in Latin America: Rebuilding and Reclaiming the State after Crisis' Development and Change 43 (1): 1-21.

Gudynas, E. (2009) 'Diez Tesis Urgentes Sobre El Nuevo Extractivismo. Contextos Y Demandas Bajo El Progresismo Sudamericano Actual' (Ten Urgent Theses about the New Extractivism. Contexts and Demands under the Current South American Progressivism) Extractivismo, Política Y Sociedad. Quito: CAAP (Centro Andino de Acción Popular) and CLAES (Centro Latino Americano de Ecología Social).

Gudynas, E. (2010a) 'Si Eres Tan Progresista ¿Por Qué Destruyes La Naturaleza? Neoextractivismo, Izquierda Y Alternativas' (If You Are So Progressive, Why Do You Destroy Nature? Neo-extractivism, the Left and Alternatives) Ecuador Debate (79): 61-81.

Gudynas, E. (2010b) 'Agropecuaria Y Nuevo Extractivismo Bajo Los Gobiernos Progresistas de América Del Sur' (Agriculture and the New Extractivism under Progressive Governments in South America) Territorios (5): 37-54.

Gudynas, E. (2011) 'Alcances Y Contenidos de Las Transiciones Al PostExtractivismo' (The Scope and the Contents of the Transitions to PostExtractivism) Ecuador Debate (82): 61-79.

Gudynas, E. (2014) 'Sustentación, Aceptación y Legitimación de los Extractivismos: Múltiples Expresiones pero un Mismo Basamento' (Support, Acceptance and Legitimization of Extractivism: Multiple Expressions but the Same Base) OPERA (14): 137-59. 
Karen M. Siegel (2016) "Neo-extractivism and democracy in South America" Development and Change, 47(3): 495-516

Haarstad, H. (2012a) 'Extracting Justice? Critical Themes and Challenges in Latin American Natural Resource Governance' in Haarstad, H. (ed.) New Political Spaces in Latin American Natural Resource Governance. New York: Palgrave Macmillan.

Haarstad, H. (ed.) (2012b) New Political Spaces in Latin American Natural Resource Governance. New York: Palgrave Macmillan.

Haarstad, H. (2012c) 'Conclusions' in Haarstad, H. (ed.) New Political Spaces in Latin American Natural Resource Governance. New York: Palgrave Macmillan.

Haarstad, H. and C. Campero (2012) 'Extraction, Regional Integration, and the Enduring Problem of Local Political Spaces' in Haarstad, H. (ed.) New Political Spaces in Latin American Natural Resource Governance, pp. 83-105. New York: Palgrave Macmillan.

Hochstetler, K. (2011) 'Under Construction - Debating the Region in South America' in Elliott, L. and Breslin, S. (eds) Comparative Environmental Regionalism, pp. 130-46. Oxon: Routledge.

Hochstetler, K. (2013) 'South-South Trade and the Environment: A Brazilian Case Study' Global Environmental Politics 13 (1): 30-48.

Hochstetler, K. and M.E. Keck (2007) Greening Brazil - Environmental Activism in State and Society. Durham and London: Duke University Press.

Hogenboom, B. (2012) 'Depoliticized and Repoliticized Minerals in Latin America' Journal of Developing Societies 28 (2): 133-58.

Humphreys Bebbington, D. and A. Bebbington (2012) 'Post-What? Extractive Industries, Narratives of Development, and Socio-Environmental Disputes across the (Ostensibly Changing) Andean Region' in Haarstad, H. (ed.) New Political Spaces in Latin American Natural Resource Governance, pp. 17-37. New York: Palgrave Macmillan.

IDB (2013) More than Revenue: Taxation as a Development Tool. http://idbdocs.iadb.org/wsdocs/getdocument.aspx?docnum=37768292 (accessed 27 May 2015)

Iglesias, V. and J. Taks (eds) (2009) Acuífero Guaraní, Por Una Gestión Participativa. Voces Y Propuestas Desde El Movimiento Del Agua (The Guaraní Aquifer, for a Participatory Management. Voices and Proposals from the Water Movement). Montevideo: Casa Bertolt Brecht.

Kaldor, M. and I. Vejvoda (1997) 'Democratization in Central and East European Countries' International Affairs 73 (1): 59-82. 
Karen M. Siegel (2016) "Neo-extractivism and democracy in South America" Development and Change, 47(3): 495-516

Lambert, P. and A. Nickson (2013) 'Epilogue: The Impeachment of President Fernando Lugo' in Lambert, P. and Nickson, A. (eds) The Paraguay Reader, pp. 451-55. Durham and London: Duke University Press.

Moore, J. and T. Velásquez (2012) 'Sovereignty Negotiated - Anti-Mining Movements, the State and Multinational Mining Companies under Correa's 21st Century Socialism"” in Bebbington, A. (ed.) Social Conflict, Economic Development and Extractive Industry - Evidence from South America. Oxon: Routledge.

Mumme, S.P. and E. Korzetz (1997) 'Democratization, Politics, and Environmental Reform' in MacDonald, G.J., Nielson, D.L., and Stern, M.A. (eds) Latin American Environmental Policy in International Perspective. Oxford: Westview Press.

Newell, P. (2008) 'Trade and Biotechnology in Latin America: Democratization, Contestation and the Politics of Mobilization' Journal of Agrarian Change 8 (2 and 3): $345-76$.

Newell, P. (2009) 'Bio-Hegemony: The Political Economy of Agricultural Biotechnology in Argentina' Journal of Latin American Studies 41 (1): 27-57.

Obarrio, M. (2007) 'Desplazan a Estrada Oyuela de su cargo en la Cancillería' (Estrada Oyuela Is Being Removed from his Position in the Foreign Office) $L a$ Nacion, 22 September 2007. http://www.lanacion.com.ar/946316-desplazan-aestrada-oyuela-de-su-cargo-en-la-cancilleria (accessed 15 September 2014).

Panizza, F. (2009) Contemporary Latin America - Development and Democracy Beyond the Washington Consensus. London: Zed Books.

Pellegrini, L. and M.O. Ribera Arismendi (2012) 'Consultation, Compensation and Extraction in Bolivia after the "Left Turn": The Case of Oil Exploration in the North of La Paz Department' Journal of Latin American Geography 11 (2): 10320.

Perreault, T. (2008) 'Popular Protest and Unpopular Policies: State Restructuring, Resource Conflict, and Social Justice in Bolivia' in Carruthers, D. V (ed.) Environmental Justice in Latin America - Problems, Promise, and Practice, pp. 239-62. London: MIT Press.

Peters, I. (2011) 'Der Belo Monte Staudamm: Paradebeispiel für eine erfolgreiche Zivilgesellschaft in Brasilien?' (The Belo Monte Dam: A Prime Example of a Successful Civil Society in Brazil?) GIGA Focus Lateinamerika No. 9/2011. Hamburg: German Institute of Global and Area Studies. http://www.gigahamburg.de/de/publikationen/giga-focus/lateinamerika (accessed 15 September 2014).

Prevost, G., H.E. Vanden, and C. Oliva Campos (2012) 'Introduction,” in Prevost, G., Oliva Campos, C., and Vanden, H.E. (eds) Social Movements and Leftist 
Karen M. Siegel (2016) "Neo-extractivism and democracy in South America" Development and Change, 47(3): 495-516

Governments in Latin America: Confrontation or Co-Optation?, pp. 1-21. London: Zed Books.

Riggirozzi, P. (2012) 'Region, Regionness and Regionalism in Latin America: Towards a New Synthesis' New Political Economy 17 (4): 421-43.

Riggirozzi, P. and D. Tussie (2012) 'Postlude' in Riggirozzi, P. and Tussie, D. (eds) The Rise of Post-Hegemonic Regionalism - The Case of Latin America, pp. 18389. Dordrecht: Springer.

Rivera-Quiñones, M.A. (2014) 'Macroeconomic Governance in Post-Neoliberal Argentina and the Relentless Power of TNCs: The Case of the Soy Complex' in Levey, C., Ozarow, D., and Wylde, C. (eds) Argentina since the 2001 Crisis Recovering the Past, Reclaiming the Future. New York: Palgrave Macmillan.

Robinson, W.I. (2008) Latin America and Global Capitalism - A Critical Globalization Perspective. Baltimore: The John Hopkins University Press.

Saad-Filho, A. (2015) 'Brazil: The Débâcle of the PT' Latin America Bureau. http://lab.org.uk/brazil-debacle (accessed 15 June 2015)

Saguier, M. (2012) 'Socio-Environmental Regionalism in South America: Tensions in New Development Models' in Riggirozzi, P. and Tussie, D. (eds) The Rise of Post-Hegemonic Regionalism - The Case of Latin America, pp. 125-45. Dordrecht: Springer.

Schilling-Vacaflor, A. (2013) 'Prior Consultations in Plurinational Bolivia: Democracy, Rights and Real Life Experiences' Latin American and Caribbean Ethnic Studies 8 (2): 202-20.

Schilling-Vacaflor, A. (2014) 'Contestations over Indigenous Participation in Bolivia's Extractive Industry: Ideology, Practices, and Legal Norms' GIGA Working Papers No. 254/2014. Hamburg: German Institute of Global and Area Studies. http://www.giga-hamburg.de/de/publikationen/working-papers (accessed 25 June 2015)

Secretaría General de la UNASUR (2013) 'La Discusión Sobre Recursos Naturales No Se Detendrá en UNASUR' (The Discussion on Natural Resources Does Not Stop in Unasur) Prensa Unasur, 3 June 2013. Quito. http://www.unasursg.org/inicio/centro-de-noticias/archivo-de-noticias/ladiscusi\%C3\%B3n-sobre-recursos-naturales-no-se-detendr\%C3\%A1-en-unasur (accessed 17 September 2014)

Segovia, D. (2009) 'Un Acuífero Guaraní Sin Guaraníes' (A Guaraní Aquifer Without Guaraníes) in Celiberti, L. and Taks, J. (eds) El Acuífero Guaraní En Debate. Montevideo: Cotidiano Mujer.

Siegel, K.M. (2014) Regional Environmental Cooperation in the Southern Cone: Which Forms does it take and Why?. PhD thesis, University of Glasgow 
Karen M. Siegel (2016) "Neo-extractivism and democracy in South America" Development and Change, 47(3): 495-516

Silva, E. (2009) Challenging Neoliberalism in Latin America. Cambridge: Cambridge University Press.

Svampa, M. (2012) 'Consenso de Los Commodities, Giro Ecoterritorial Y Pensamiento Crítico En América Latina' (Consensus of Commodities, Ecoterritorial Shifts and Critical Thinking in Latin America) Observatorio Social de América Latina. Buenos Aires: CLACSO.

Veltmeyer, H. and J. Petras (eds) (2014) The New Extractivism: A Post-Neoliberal Development Model or Imperialism of the Twenty-First Century? London: Zed Books.

Vergara-Camus, L. (2015) 'Sugarcane Ethanol: The Hen of the Golden Eggs? Agribusiness and the State in Lula's Brazil' in Spronk, S.J. and Webber, J.R. (eds) Crisis and Contradiction: Marxist Perspectives on Latin America in the Global Economy. Leiden: Brill Academic Publishers.

Waisbord, S. and E. Peruzzotti (2009) 'The Environmental Story That Wasn't: Advocacy, Journalism and the Asambleismo Movement in Argentina' Media, Culture \& Society 31 (5): 691-709.

Wandscheer, N. (2009) 'La Lucha Contra Los Agrotóxicos En Mato Grosso' (The Fight Against Agro-chemicals in Mato Grosso) in Celiberti, L. and Taks, J. (eds) El Acuífero Guaraní En Debate. Montevideo: Cotidiano Mujer.

Weyland, K. (2009) 'The Rise of Latin America's Two Lefts: Insights from Rentier State Theory' Comparative Politics 41 (2): 145-64.

Wolff, J. (2013) 'Towards Post-Liberal Democracy in Latin America? A Conceptual Framework Applied to Bolivia' Journal of Latin American Studies 45 (1): 31-59.

Wolford, W. (2008) 'Environmental Justice and Agricultural Development in the Brazilian Cerrado' in Carruthers, D. V (ed.) Environmental Justice in Latin America - Problems, Promise, and Practice, pp. 212-37. London: MIT Press.

Yanosky, A. (2013) 'The Challenge of Conserving a Natural Chaco Habitat in the Face of Severe Deforestation Pressure and Human Development Needs' in Lambert, P. and Nickson, A. (eds) The Paraguay Reader, pp. 376-81. Durham and London: Duke University Press.

Zenteno Hopp, J., E. Hanche-Olsen, and H. Sejenovich (2015) 'Argentina Government-Agribusiness Elite Dynamics and Its Consequences for Environmental Governance' in Bull, B. and Aguilar-Støen, M. (eds) Environmental Politics in Latin America - Elite Dynamics, the Left Tide and Sustainable Development. Oxon: Routledge.

Zibechi, R. (2010) 'Vorwärts in Die Vergangenheit - Der Linke Weg Zurück Zur Schweiz Lateinamerikas' (Forwards into the Past - The Path of the Left Back to the Switzerland of Latin America) in Thimmel, S., Bruns, T., Eisenbürger, G., 
Karen M. Siegel (2016) "Neo-extractivism and democracy in South America" Development and Change, 47(3): 495-516

and Weyde, B. (eds) Uruguay - Ein Land in Bewegung (Uruguay - A Country in Motion). Berlin: Assoziation A. 